\title{
ANALISIS YURIDIS TINDAK PIDANA MEMPRODUKSI DAN MENGEDARKAN SEDIAAN FARMASI DAN/ATAU ALAT KESEHATAN YANG TIDAK MEMILIKI IZIN EDAR (Putusan Nomor:45/PIDSUS/2016/PN \\ Mtw)
}

\section{Iqbal Besaringga ${ }^{1}$, Rico Dekha Christiady Sihombing ${ }^{2}$}

${ }^{1}$ Fakultas Hukum, Universitas Prima Indonesia, email: iqbalbesaringga1504@gmail.com

\section{ABSTRACT}

Health is a very important thing in human life. However, nowadays there are more and more crimes in the health sector, one of which is the crime of distributing pharmaceutical preparations and medical devices without a license to distribute them, so serious handling is needed in an effort to eradicate these crimes. The sources of data used in this study are primary and secondary, namely data collection through literature studies and legislation related to the problems in this journal. In criminal liability, the defendant can be held criminally responsible and the judge's decision is also correct because it considers the elements in Article 197 Jo 106 paragraph 1 and 3 of UURI NO 36 of 2009. However, in giving a sentence of 1 year in prison and a fine of Rp. 10,000,000 still too little, considering the amount of medicine he circulated was very large, namely 110 Zenith Carnophein pills. The conclusion that we take is that because the elements of the indictment handed down to the defendant have been fulfilled, then in criminal liability, the defendant must be responsible for what he has done in accordance with the criminal threat that has been imposed on him.

\section{ARTICLE INFO}

\section{Keywords:}

health, crime; pharmaceutical

preparations

\section{Cite this paper:}

Iqbal Besaringga, R. D. (2021).

Analisis Yuridis Tindak Pidana

Memproduksi Dan Mengedarkan

Sediaan Farmasi Dan/Atau Alat

Kesehatan Yang Tidak Memiliki

Izin Edar (Putusan

Nomor:45/PIDSUS/2016/PN

Mtw). Widya Yuridika: Jurnal

Hukum, 4(2).

Scope Article

Criminal Law

\section{PENDAHULUAN}

Kesehatan ialah hal penting di setiap kehidupan manusia, kesehatan yang baik adalah suatu dambaan bagi seluruh manusia termasuk bagi seluruh Negara di dunia ini. Semua Negara berlomba-lomba dalam memperbaiki sistem kesehatan di Negara mereka tak terkecuali di Indonesia. Sebab menjadi hal yang paling utama, untuk itu hendaklah pemerintah membangun kesehatan yang layak guna memperbaiki sistem kesehatan. ${ }^{1}$

Instrumen dari pembangunan nasional yakni pembangunan kesehatan yang bertujuan meningkatkan kesadaran hidup sehat di masyarakat. ${ }^{2}$ Disamping itu, kesehatan juga berguna dalam mengetahui perkembangan suatu bangsa serta dapat mewujudkan

\footnotetext{
${ }^{1}$ Muhammad Sadi IS, Etika dan Hukum kesehatan Teori dan Aplikasinya di Indonesia, hlm.13.

${ }^{2}$ NS Ta'adi, hukum kesehatan:sanksi dan motivasi bagi perawat, hlm 5
} 
masyarakat yang berkeadilan serta makmur. Kesehatan juga merupakan hak asasi yang ada pada manusia dan suatu hal yang mempengaruhi majunya suatu bangsa. ${ }^{3}$

Ada beberapa kewajiban Negara berkaitan dengan hak atas kesehatan yaitu yang pertama adalah menghormati hak atas kesehatan, yakni dalam hal ini Negara wajib hukumnya dalam menahan diri agar tidak melakukan suatu perbuatan yang dapat mengakibatkan dampak negative bagi kesehatan. Yang kedua, melindungi hak atas kesehatan, yakni dalam hal ini Negara menjamin suatu persamaan akses jasa kesehatan yang disediakan oleh pihak ketiga, serta membuat peraturan-peraturan yang sifatnya melindungi. Dan yang ketiga yaitu memenuhi hak atas kesehatan, yakni dalam hal ini pemerintah menyediakan fasilitas-fasilitas serta pelayanan kesehatan bagi masyarakatnya. ${ }^{4}$

Pembangunan kesehatan merupakan salah satu upaya peningkatan aspek fisik serta biologis dari manusia. kesehatan yang baik adalah penunjuk dari sumber daya yang baik dan cemerlang. ${ }^{5}$ Tanpa kesehatan, manusia takkan bisa hidup produktif serta layak secara ekonomi dan juga dalam menjalani pendidikan yang berkualitas. ${ }^{6}$

Dan saat ini perkembangan kesehatan di indonesia mulai mengalami perkembangan dan pertumbuhan yang sangat cepat dan pesat. Namun, semakin berkembangnya pembangunan kesehatan di indonesia, semakin banyak pula terjadi berbagai macam bentuk kejahatan kesehatan di indonesia.

Salah satunya yakni dengan sengaja mengedarkan sediaan farmasi dan alat kesehatan tanpa mempunyai izin untuk mengedarkannya. Sediaan farmasi menurut Undang-Undang Nomor 36 Tahun 2009 Tentang kesehatan ialah obat, bahan obat, obat tradisional, dan kosmetika.

Sedangkan, alat kesehatan adalah instrumen, apparatus, mesin dan/atau implant yang tidak mengandung obat yang digunakan untuk mencegah, mendiagnosis, menyembuhkan dan meringankan penyakit, merawat orang sakit, memulihkan kesehatan pada manusia, dan/atau membentuk struktur dan memperbaiki fungsi tubuh.

Seseorang hanya dapat mengedarkan jika telah mendapatkan izin mengedarkannya. Dan bagi siapapun jika melanggar maka dinyatakan melakukan perbuatan tindak pidana.dan saat ini kasus seperti ini marak terjadi dimasyarakat. Penyebabnya adalah masyarakat dengan mudah mendapatkannya dengan harga yang sangat terjangkau.

Hukum kesehatan merupakan segala peraturan hokum yang berkaitan dengan pemeliharaan dan pelayanan kesehatan. Segalanya menyangkut hak serta kewajiban perorangan dan seluruh lapisan masyarakat termasuk pelayanan dalam kesehatan dengan semua aspeknya. ${ }^{7}$

Di Indonesia peraturan perundang-undangan yang mengatur tentang kesehatan yakni Undang-undang nomor 36 tahun 2009 Tentang kesehatan

Berdasarkan latar belakang tersebut, maka kami sebagai penulis sangat terdorong untuk mengangkat judul "Analisis Yuridis Tindak Pidana Memproduksi dan Mengedarkan Sediaan farmasi dan/atau Alat Kesehatan Yang Tidak Memiliki Izin Edar" (PUTUSAN NOMOR: 45/PIDSUS/2016/PN Mtw)".

\footnotetext{
${ }^{3}$ Andin Rusmini,(September-Desember, 2016),Tindak Pidana Pengedaran dan Penyalahgunaan Obat Farmasi Tanpa Izin Edar Menurut Undang-undang Nomor 36 Tahun 2009 Tentang Kesehatan, Al'Adl, Volume 8, Nomor 3, hlm 25

${ }^{4}$ Indar, dkk, Hukum Dan Bioetik Dalam Perspektif Etika Dan Hukum Kesehatan, hlm 17

${ }^{5}$ Soekidjo Notoatmodjo,Etika dan hukum kesehatan, hlm 19

${ }^{6}$ Sri Siswati, Etika dan Hukum Kesehatan dalam Perspektif Undang-undang kesehatan, hlm 2

${ }^{7}$ AdminAlfa, Hukum Kesehatan, Diambil dari: http://www.sangkoeno.com/2014/10/hukum-kesehatan.html?m=1
} 
Rumusan Masalah yang penulis angkat dalam penelitian ini yakni tentang bagaimana pertanggungjawaban pidana pelaku tindak pidana memproduksi atau mengedarkan sediaan farmasi dan/atau alat kesehatan yang tidak memiliki izin edar di dalam putusan NOMOR: 45/PIDSUS/2016/PN Mtw dan Bagaimana kebijakan hakim atas tindak pidana memproduksi atau mengedarkan sediaan farmasi dan/atau alat kesehatan yang tidak memiliki izin edar di dalam putusan NOMOR: 45/PIDSUS/2016/PN Mtw

Tujuan penelitian ini yaitu guna mengetahui dan menganalisis pertanggungjawaban pidana pelaku tindak pidana memproduksi atau mengedarkan sediaan farmasi dan/atau alat kesehatan yang tidak memiliki izin edar dalam putusan NOMOR: 45/PIDSUS/2016/PN Mtw serta Guna mengetahui dan menganalisis kebijakan hakim atas tindak pidana memproduksi atau mengedarkan sediaan farmasi dan/atau alat kesehatan yang tidak memiliki izin edar dalam putusan NOMOR: 45/PIDSUS/2016/PN Mtw.

Manfaat Penelitian dalam penelitian ini yakni yang pertama Manfaat teoritis yaitu untuk memberi penjelasan hasil dari penelitian sebagai pemberi pemikiran serta memperbanyak konsepsi, teori-teori yang berkaitan dengan ilmu suatu penelitian. ${ }^{8}$ Dan yang kedua yaitu Manfaat praktis yakni untuk memberi penjelasan hasil penelitian sebagai pemberi pemikiran untuk memecahkan masalah yang berkaitan dalam topik maupun tema sentral. ${ }^{9}$

\section{METODE}

Jenis penelitian yang diambil dalam penelitian ini menggunakan jenis yuridis normatif. Yuridis normatif merupakan jenis penelitian yang bersifat kepustakaan, dimana sumber penelitian diambil dari buku-buku, undang-undang serta tulisan yang terkait. Sifat Penelitian yang digunakan dalam penelitian ini menggunakan penelitian deskriptif yakni penelitian yang bersifat menggambarkan serta memaparkan masalah berkaitan dengan penelitian. Sumber bahan hukum yang digunakan adalah data sekunder yaitu mengumpulkan data yang telah ada sebelumnya (perpustakaan), seperti buku-buku, undang-undang, serta tulisan yang terkait.

1. Bahan hukum primer meliputi:

- UU Nomor 36 Tahun 2009 Tentang Kesehatan

- Kitab Undang-undang Hukum Acara Pidana

2. Bahan hukum sekunder yakni bahan yang memberi penjelasan tentang bahan hukum primer, contoh: buku, UU serta tulisan yang berkaitan

3. Bahan hukum tersier yakni yang memberi penjelasan tentang bahan hukum sekunder, contoh: KBBI dan Internet

Pengumpulan data yang dipakai yakni dengan mempelajari buku-buku serta dokumen (putusan) dan juga menganalisa bahan-bahan pustaka yang terkait.

Analisis data yang dipakai dalam penelitian yakni analisis kualitatif yaitu dengan menjawab dan memecahkan masalah dari pertanyaan-pertanyaan yang bersumber dari buku atau perundang-undangan.

\section{HASIL DAN PEMBAHASAN}

Pertanggungjawaban Pidana Pelaku Tindak Pidana Memproduksi Atau Mengedarkan Sediaan Farmasi Dan/Atau Alat Kesehatan Yang Tidak Memiliki Izin Edar (NO: 45/PIDSUS/2016/PN Mtw)

Pertanggungjawaban pidana merupakan pemberian hukuman kepada pembuat sebab suatu perbuatan yang melanggar larangan dan juga menyebabkan kejadian yang terlarang.

\footnotetext{
${ }^{8}$ Suteki dan Galang Taufani, Metodologi Penelitian Hukum (Filsafat, Teori Dan Praktik), hlm 207

${ }^{9}$ Ibid
} 
Pertanggungjawaban pidana dilihat dari kesalahan pembuat dan bukan hanya dari terpenuhinya semua unsur tindak pidana. Menurut simons, kesalahan yang ada dalam jiwa pelaku yang berhubungan dengan kelakuan yang bisa dipidana dan sesuai dengan kejiwaan pelaku dapat dicela karena perbuatannya sebab merupakan dasar dari pertanggungjawaban pidana. Adanya kesalahan yang terdapat dalam diri pelaku mesti ditentukan hal yang berkaitan sebagai berikut: 10

1. Kemampuan dalam bertanggungjawab

2. Hubungan, kejiwaan yang ada diantara para pelaku dan akibat yang akan ditimbulkan ( termasuk di dalamnya kelakuan yang tidak bertentangan sama sekali di dalam hokum serta di dalam kehidupan sehari-hari

3. Dolus dan culpa, kesalahan yang merupakan unsur subjektif di dalam tindak pidana. Dalam hal ini merupakan konsekuensi pendapatnya menyatukan kesalahan dengan straafbaarfeit.

Secara sempit kesalahan dianggap berkesesuaian dengan kealpaan, yakni kata kesalahan dianggap mempunyai makna kata yang sama dengan sifat ketidak hati-hatian. Selanjutnya, kesalahan juga dianggap sama dengan alasan penghapus yang terdapat di luar undang-undang. Dengan ini, tidak adanya suatu kesalahan sama sekali atau afwezigheid van alle schuld (avas), dirujuk sebagai suatu alasan penghapus pidana diluar dari yang ditentukan di dalam UU. Kesalahan juga dipakai sebagai nama gabungan dari kesengajaan dan kealpaan. Dapat dikatakannya kesalahan jika di dalam diri si pembuat ada terdapat satu dari dua bentuk kesalahan, saat melakukan suatu tindak pidana. Dan didalam suatu lapangan hukum pidana yang merujuk kepada asas praduga tak bersalah, kesalahan dapat diartikan sebagai telah melakukan suatu perbuatan tindak pidana. ${ }^{11}$

Keseluruhan pengertian seperti yang telah disebutkan, pada umumnya berkaitan dengan suatu kenyataan bahwasaannya kesalahan merupakan suatu bagian inti dari tindak pidana, yang berisi tentang keadaan psikologis dari si pembuat, pada saat melakukan suatu tindak pidana. ${ }^{12}$

Posisi Kasus dalam putusan ini bahwa ia terdakwa Suryadi Als Bin Idrus pada hari Selasa tanggal 15 Desember 2015 pukul 15.30 wib. Pada bulan Desember tahun 2015 di Jalan Merak Barak milik Haji Mahmud nomor 13 Kelurahan Melayu Kecamatan Teweh Tengah Kabupaten Barut pada suatu tempat lain yang masih termasuk didaerah hukum Pengadilan Negeri Muara Teweh yang berwenang memeriksa dan mengadili perkara ini "dengan sengaja memproduksi atau mengedarkan sediaan farmasi dan/atau alat kesehatan yang tidak memiliki izin edar sebagaimana dimaksud dalam pasal 106 ayat (1) dan (3)" yaitu berupa 110 (seratus sepuluh) butir obat jenis Zenith Carnophen.

Dakwaan dalam hal ini perbuatan terdakwa diancam pidana diatur dalam Pasal 197 Jo Pasal 106 ayat (1) dan (3) Undang-Undang RI Nomor 36 Tahun 2009 Tentang Kesehatan

Analisis penulis dalam putusan ini, penuntut umum memberikan terdakwa dakwaan tunggal dan terdakwa penulis anggap dapat bertanggungjawab karena dalam keadaan sehat dan tidak cacat mental maupun jiwanya. Dakwaan yang diberikan kepada terdakwa didalam kasus ini juga sudah tepat, sebab berdasarkan dari fakta-fakta yang didapat. Maka menurut penulis wajar jika penuntut umum memberikan dakwaan yang sesuai dengan perbuatannya.

\footnotetext{
${ }^{10}$ Admin, Teori Pertanggungjawaban Pidana, Diambil dari: https://info-hukum.com/2019/04/20/teoripertanggungjawaban-pidana/\#-ftn1

${ }^{11}$ Chairul Huda, Dari Tiada Pidana Tanpa Kesalahan Menuju Kepada Tiada Pertanggungjawaban Pidana

Tanpa Kesalahan, hlm 74-75

12 Ibid
} 
Kebijakan Hakim Atas Tindak Pidana Memproduksi Atau Mengedarkan Sediaan Farmasi Dan/Atau Alat Kesehatan Yang Tidak Memiliki Izin Edar (NO: 45/PIDSUS/2016/PN Mtw)

Pertimbangan hakim merupakan hal penting dalam mewujudkan keadilan serta terdapat manfaat bagi pihak yang bersangkutan, sehingga pertimbangan harus dianalisis secara cermat. ${ }^{13}$

Dalam putusan ini Majelis hakim mempertimbangkan sebagai berikut:

Menimbang bahwa oleh karena semua unsur dari pasal 197 jo 106 ayat (1) dan (3) UU RI No. 36 Tahun 2009 tentang kesehatan telah terpenuhi, maka terdakwa haruslah dinyatakan telah terbukti secara sah dan meyakinkan melakukan tindak pidana dalam dakwaan tunggal.

Menimbang bahwa terhadap barang bukti yang diajukan di persidangan dan di pertimbangkan sebagai berikut:

Menimbang bahwa barang bukti berupa seratus sepuluh butir obat Carnophen (Zenith), tas sandang berwarna hitam merk poloarmy karena merupakan obat yang sudah ditarik izin edarnya dan juga digunakan untuk melakukan tindak pidana maka berdasarkan pasal 46 KUHAP maka barang bukti tersebut haruslah dinyatakan dirampas untuk dimusnahkan

Dan majelis hakim pada pokoknya memutuskan:

Menjatuhkan pidana kepada terdakwa oleh karena itu dengan pidana penjara selama 1 (satu) tahun dan denda sebesar Rp.10.000.000,- (sepuluh juta rupiah) dengan ketentuan jika pidana denda tersebut tidak dibayar diganti dengan pidana kurungan selama 2 (dua) bulan

Menetapkan penangkapan serta penahanan yang telah dijalani terdakwa dikurangi seluruh dari pidana yang dijatuhkan

Analisis Penulis yakni di dalam KUHAP dijelaskan bahwa hakim adalah pejabat peradilan Negara yang diberikan kewenangan oleh UU dalam mengadili. Seorang hakim juga harus memiliki prinsip pedoman perilaku di dalam dirinya, diantara perilaku tersebut yakni sebagai berikut ${ }^{14}$ :

1. Mempunyai perilaku yang adil

2. Mempunyai perilaku yang jujur

3. Mempunyai perilaku yang arif dan bijaksana

4. Bersikap mandiri

5. Seorang hakim harus berintegritas tinggi

6. Bertanggungjawab

7. Dapat menjunjung tinggi harga diri

8. Mempunyai kedisiplinan yang tinggi

9. Mempunyai perilaku yang rendah hati, serta

10. profesional

Dan dijelaskan pernyataan hakim yang diucapkan pengadilan terbuka disebut putusan pengadilan, berbentuk pemidanaan, bebas atau lepas menurut undang-undang.

\footnotetext{
13 Marianti D, (Juni, 2020),Tinjauan yuridis terhadap penjatuhan hukuman dalam tindak pidana penjualan obat-obatan tanpa izin, doktrina:journal of law, Volume 3, Nomor 1, hlm 5

${ }^{14}$ PN Muaro Kelas II, Kode Etik Hakim, Diambil dari http//pn-muaro.go.id/index.php/tentangpengadilan/tugas-wewenang-dan-fungsi/9-pn-muaro/tentang-pengadilan/profil-pengadilan
} 
Dalam memutuskan atau mengadili seseorang, hakim tidaklah boleh jika hanya berdasarkan keyakinannya saja. Sebab ketika seseorang sudah merasa memiliki cukup alasan bahwa pengetahuannya itu benar, berarti ia sudah memiliki keyakinan. Akan tetapi, keyakinan tidaklah mungkin selalu benar. Sebab keyakinan hanya menunjukkan sikap mental manusianya, seseorang merasa yakin sebab sudah cukup alasan bahwa pengetahuannya itu benar.

Namun, keyakinan semata bukan jaminan kebenaran. ${ }^{15}$ Jadi ketika akan memutuskan hakim hendaklah mempertimbangkan fakta-fakta di persidangan dan harus diikuti alat bukti yang sah minimal berjumlah dua. Sebagaimana terkandung di dalam KUHAP pasal 183:

"Hakim tidak boleh menjatuhkan pidana kepada seorang kecuali apabila dengan sekurang-kurangnya dua alat bukti yang sah ia memperoleh keyakinan bahwa suatu tindak pidana benar-benar terjadi dan bahwa terdakwalah yang bersalah melakukannya" 16

Dan jika alat bukti yang didapat oleh penegak hukum tidak sah maka tidak memiliki nilai pembuktian sehingga harus diabaikan oleh hakim. ${ }^{17}$ Adapun di dalam peraturan hukum Indonesia, tepatnya didalam KUHAP dijelaskan Alat bukti yang sah yakni:

1. Keterangan saksi

2. Ahli

3. Surat

4. Petunjuk

5. Keterangan terdakwa.

Di putusan ini penulis berpendapat bahwa Majelis Hakim telah tepat, sebab memperhatikan beberapa hal yakni telah terpenuhinya:

1. Unsur setiap orang,

2. Unsur dengan sengaja

3. Unsur pemerintah berwenang mencabut izin edar

Dan memperhatikan dakwaan tunggal yang didakwakan oleh penuntut umum beserta peraturan perundang-undangan lain yang bersangkutan, majelis hakim juga memperhatikan hal yang meringankan seperti terdakwa yang mengakui serta menyesal akan perbuatannya serta hal yang memberatkan yakni perbuatannya meresahkan masyarakat dan tidak mendukung program pemerintah dalam memberantas tindak pidana penyalahgunaan obat. Disamping itu majelis hakim juga telah memperhatikan keterangan saksi dan keterangan terdakwa beserta barang bukti yang didapat. Namun dalam pemberian hukuman 1 tahun dan denda sebesar Rp.10.000.000 kepada terdakwa kami berpendapat masih kurang atau terlalu sedikit, sebab di dalam pasal 197 Undang-undang RI NO 36 Thn 2009 hukuman paling lama yakni 15 tahun dan denda paling banyak Rp.1.500.000.000. Mengingat apa yang dilakukan terdakwa dengan mengedarkan 110 butir obat zenith carnophein tersebut, maka sepatutnya Terdakwa dapat dijatuhi hukuman lebih dari itu, sebab jumlah 110 butir bukanlah jumlah yang sedikit, sudah banyak korban yang merasakan efek negatif dari perbuatannya, untuk itu maka pantaslah jika terdakwa dapat dihukum lebih dari 1 tahun dan denda lebih dari Rp.10.000.000.

\section{PENUTUP}

\footnotetext{
${ }_{15}$ Dani Vardiansyah dan Erna Febriani, Filsafat Ilmu Komunikasi Pengantar Ontologi, Epistemologi Aksiologi, hlm 7

16 Pasal 183 KUHAP

17 Boris Tampubolon SH, Hakim Tidak Boleh Memutus Orang Bersalah Hanya Berdasarkan Keyakinan Saja, Diambil dari https://konsultanhukum.web.id/hakim-tidak-boleh-memutus-orang-bersalah-hanyaberdasarkan-keyakinan-saja/
} 
1. Dalam pertanggungjawaban pidana, terdakwa telah memenuhi unsur-unsur dakwaan yaitu dengan sengaja memproduksi ataupun mengedarkan sediaan farmasi dan alat kesehatan tanpa izin edar.

2. Dalam putusan ini, Majelis hakim memberikan pidana penjara kepada terdakwa suryadi als suri bin idrus 1 tahun dan denda sebanyak Rp.10.000.000 (sepuluh juta rupiah).

\section{SARAN}

1. Sebab telah terpenuhinya unsur-unsur dakwaan yang dijatuhkan kepadanya, maka dalam pertanggungjawaban pidana, terdakwa harus mempertanggungjawabkan apa yang telah ia perbuat sesuai dengan ancaman pidana yang telah dijatuhkan terhadapnya.

2. Dalam menjatuhkan hukuman pidana, majelis hakim hendaklah memperhatikan keadilan, kepastian hukum, serta kemanfaatan, yang mana ketiganya harus seimbang dengan begitu tujuan hokum juga akan tercapai sesuai dengan yang diharapkan.

\section{DAFTAR PUSTAKA}

\section{Peraturan Perundang-undangan}

Kitab Undang-undang Hukum Acara Pidana

UU RI Nomor 36 Tahun 2009 Tentang Kesehatan

\section{Buku}

Huda Chairul, (2008), Dari Tiada Pidana Tanpa Kesalahan Menuju Kepada Tiada Pertanggungjawaban Pidana Tanpa Kesalahan, Jakarta: Kencana Prenada Media Group

Indar, dkk, (2019) Hukum Dan Bioetik Dalam Perspektif Etika Dan Hukum Kesehatan, Yogyakarta: Penerbit Deepublish

IS, Sadi Muhamad, (2015), Etika dan Hukum Kesehatan Teori dan Aplikasinya di Indonesia, Jakarta: kencana

Notoatmodjo, Soekidjo, (2010), Etika dan Hukum Kesehatan, Jakarta:Rineka Cipta

Siswati, Sri, (2013), Etika dan Hukum Kesehatan Dalam Perspektif Undang-undang Kesehatan, Jakarta: PT RajaGrafindo Persada

Suteki dan Galang Taufani, (2018), Metodologi Penelitian Hukum (Filsafat, Teori dan Praktik), Depok: PT RajaGrafindo Persada

Ta'adi, NS, (2012), Hukum Kesehatan:Sanksi Dan Motivasi Bagi Perawat, Jakarta:Penerbit buku kedokteran EGC

Vardiansyah, Dani dan Erna Febriani, (2018), Filsafat Ilmu Komunikasi: Pengantar Ontologi, epistemology, Aksiologi, Jakarta: Penerbit Indeks

\section{Artikel Jurnal}

Andin Rusmini, (2016),Tindak Pidana Pengedaran dan Penyalahgunaan Obat Farmasi Tanpa Izin Edar Menurut Undang-undang Nomor 36 Tahun 2009 Tentang Kesehatan, Al'Adl, Volume 8, Nomor 3.

Marianti D, (2020),Tinjauan yuridis terhadap penjatuhan hukuman dalam tindak pidana penjualan obat-obatan tanpa izin, doktrina:journal of law, Volume 3, Nomor 1.

\section{Website}


Admin, Teori Pertanggungjawaban Pidana, Diambil Oktober 02, 2020, Dari https://infohukum.com/2019/04/20/teori-pertanggungjawaban-pidana/\#-ftn1

AdminAlfa, Hukum Kesehatan, Diambil April 24, 2021, Dari http://www.sangkoeno.com/2014/10/hukum-kesehatan.html?m=1

Boris Tampubolon SH, 2016, Hakim Tidak Boleh Memutus Orang Bersalah Hanya Berdasarkan Keyakinan Saja, Diambil Oktober 2, 2020, Dari https://konsultanhukum.web.id/hakim-tidak-boleh-memutus-orang-bersalahhanya-berdasarkan-keyakinan-saja/

PN Muaro Kelas II, Kode Etik Hakim, Diambil April 25, 2021 dari http//pnmuaro.go.id/index.php/tentang-pengadilan/tugas-wewenang-dan-fungsi/9-pnmuaro/tentang-pengadilan/profil-pengadilan 